UDC 581.4:581.526.5:631.547+581.522.5

DOI: $10.15587 / 2519-8025.2020 .201320$

\title{
UNCARINA ROEOSLIANA RAUH ONTOMORPHOGENESIS IN EARLY STAGES OF DEVELOPMENT
}

\author{
M. Gaidarzhy, O. Futorna, N. Nuzhyna
}

\begin{abstract}
Мета. 3'ясувати морфологію насіння, виявити особливості його проростання та дослідити розвиток рослин Uncarina roeoesliana Rauh (Pedaliaceae) на ранніх стадіях онтоморфогенезу в зв'язку з проблемою схожості насіння та вирощування їх в умовах інтродукиії.

Матеріали та методи. Досліджено латентний та прегенеративний періоди онтоморфогенезу рослин Uncarina roеоеsliana за умов вирощування у захищеному трунті Ботанічного саду ім. акад. О. В. Фоміна. В роботі використані біоморфологічні, інтродукиійні, гістологічні методи.

Результати та їх обговорення. Розроблено метод прискорення схожості свіжозібраного насіння. Встановлено, що насінини Uncarina roеоеsliana великі за розмірами (близько 7x5 мм), переважно широкотрикутні, коричневого кольору з малопомітним крилом по всьому периметру насінини. Дорзальна сторона формує складки, рубчик знаходиться на мікропілярній частині насінини. Периклінарні стінки опуклі і часто формують папіли. Зародок великий, займає більшу частину насінини, ендосперм багатий на ліпіди, що характерно і для представника цієї ж родини Sesamuт indicum L. Ймовірно наявність папіл сприяє накопиченню вологи для активізації ферментативної діяльності при набуханні насінин. Всі цүі особливості проростання насіння узгоджуються з екологічними умовами в місиях природного розповсюдження представників роду Unсагіпа: високими температурами, невеликою кількістю опадів та значним посушливим періодом. Ймовірно рослини иьього виду відносяться до макробіотиків, тобто достатньо довго можуть зберігати схожість насіння. Проростання надземне. Впродовж 24 тижнів розвитку рослини досягають віргінільної стадї розвитку: формують редькоподібні корені, 5-6 пар листків, з яких на молодих рослинах у цій стадії залишається тільки дві пари, та потовщену базальну частину стебла.

Висновки. Порівнюючи Uncarina roеоеsliana з іншими каудексоподібними рослинами можна констатувати, щуо ия рослина має високий потенціал для вижсивання в посушливих умовах завдяки здатності рослини накопичувати вологу в базальній частині стебла і м'ясистому корінню. При цьому рослина пристосована до існування як в режимі спокою, так $і$ в режимі активного росту, але в останньому випадку тільки при наявності достатньої кількості вологи в трунті
\end{abstract}

Ключові слова: насінина, проростання, ранні етапи онтогенезу, каудексоподібна рослина, ендемік Мадагаскару

Copyright (C) 2020, M. Gaidarzhy, O. Futorna, N. Nuzhyna. This is an open access article under the CC BY license (http://creativecommons.org/licenses/by/4.0).

\section{Introduction}

Succulents are plants that grow mainly in the deserts of Central America (Cactaceae) and Africa (Euphorbiaceae), a small number of species of the genus Crassulaceae is also found in temperate climates. The main way of existence in extreme conditions in succulents - the accumulation of large reserves of water in the tissues and its extremely economical use. The bulk of aquiferous tissue (hairs and ground cells of the epidermal complex, hypodermis, inner layers of the mesophile, wood and medullar parenchyma) is formed in the leaves or stems. According to the literature, about 10 thousand species and intraspecific taxa are succulent plants belonging to more than 60 families from both classes of the division Magnoliophyta $[1,2]$. Some families are represented exclusively by succulents (Cactaceae, Aloaceae, Didiereaceae), but most families include species that are representatives of other ecological groups of plants. Since the structural organization of vegetative organs of plants reflects at the same time a number of different scales, different in pace and relatively independent in directions, processes and phenomena: some general patterns of plant morphogenesis, systematic and phylogenetic position of the species, features of ecological habitats, it is clear that members of a particular family have their own anatomical and morphological and physiological and biochemical features.

\section{Literary review}

One of the succulent plants is Uncarina roeosliana Rauh from the family Pedaliaceae, which belongs to the group of caudiciform succulents [1]. The family Pedaliaceae has more than 60 species belonging to 13 genus's. Its most famous representative is Sesamum indicum Linne (sesame), which is widely used as an edible, oily and medicinal plant [3]. Plants of the family Pedaliaceae are common in Africa, Madagascar, Australia and some islands near this continent. Representatives of the 
genus Uncarina are endemic plants of arid areas of the island of Madagascar, there are now 13 species, most of which were described in the 60 s of XX century, and some species even in 1995-1999. In particular, Uncarina roeoesliana was described in 1995 [1]. Plants of this species grow on sand dunes or in sparse forests in southwestern Madagascar, at an altitude of 100 to $500 \mathrm{~m}$ above sea level. The climate of this area is arid or semiarid and is characterized by an average annual temperature of $25-26^{\circ} \mathrm{C}$, dry season up to 7 consecutive months and rainfall from 350 to $900 \mathrm{~mm}$ per year [4].

Uncarina roeoesliana - is a weakly branched dwarf tree, up to 1.5 (2) $\mathrm{m}$ tall with a thickened basal part of the stem and succulent roots. Depending on the amount of moisture in the dry season, plants can completely lose the leaves, which are collected in rosettes at the ends of the shoots. The leaves are simple, with more or less pronounced 3-5 laminas, densely covered on both sides with trichomes. The flowers are collected in cymoid, reduced inflorescences, appear in the axils of the leaves, bisexual, zygomorphic, with a short straight peduncle, about $10 \mathrm{~mm}$ long, bright yellow [5].

We have not found any literature sources on the morphology of Uncarina roeoesliana seeds and their germination. Since the features of the anatomical structure of seeds and seed coatings are conservative and, due to evolutionary irreversibility, have high diagnostic value, playing in many cases a crucial role in taxonomic reconstructions [6-8], we investigated the ultrastructure of Uncarina roesliana seed surface. Examining the external morphology of seeds, we also tried to establish the causes of complicated seed germination in the conditions of introduction.

In the collection of succulent plants of the Botanical Garden named after acad. O. V. Fomin at the Taras Shevchenko National University of Kyiv Uncarina roeoesliana has been grown since 2005 . We previously studied the morphology of the flower, the phenology of flowering and the peculiarities of pollination, developed a method of obtaining seeds under the conditions of introduction [5].

\section{The aim and objectives of the study}

The aim of this work was to determine the morphology of seeds, to identify the peculiarities of its germination and to study the development of Uncarina roeoesliana plants in the early stages of ontomorphogenesis due to the problem of seed germination and cultivation under introduction. were set:

To achieve this goal, the following objectives

1. Study the seed morphology of Uncarina roeoesliana

2. Find out the features of growth and development of plants in the early stages of ontogenesis

3. To develop a method of germination of seeds of the studied plant species

\section{Materials and methods}

The latent and pregenerative periods of ontomorphogenesis of Uncarina roeoesliana plants under conditions of cultivation in protected soil (greenhouses of the Botanical garden named after acad. O. V. Fomin) have been studied. By the term ontomorphogenesis we mean the sequence of stages of development of an individual from seed to natural death of plants at the level of individuals. The division of the pregenerative period into separate stages took place according to the methods described in the literature [9]. A detailed morphological description of the studied plants Uncarina roeoesliana is given in [5].

Plants were grown on the succulent regime, in the soil mixture for succulents [10]. The germination of freshly harvested seeds was over $65 \%$. We found that for faster germination of seeds must be kept in distilled water from 6 to 12 hours. After that, the seeds were sown in a sterile soil mixture and covered with a thin layer of coarse sand. At a temperature of $+24-28{ }^{\circ} \mathrm{C}$ the seeds began to germinate for 8-10 days, but the maximum number of seeds germinated for 16-18 days (Fig. 1).

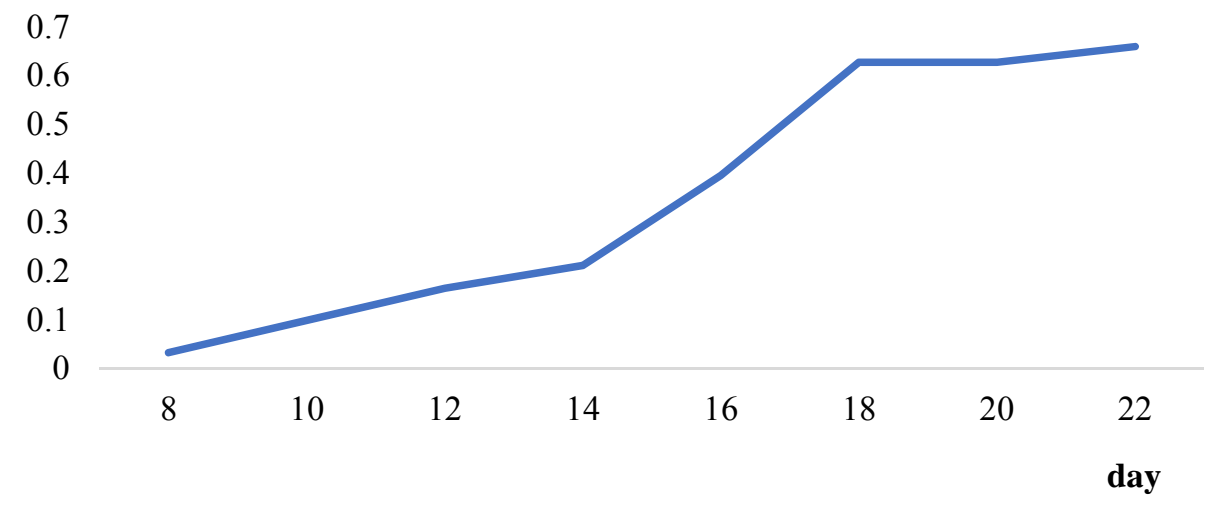

Fig. 1. Germination of freshly harvested seeds of Uncarina roeoesliana

In the study of the stages of ontomorphogenesis, measurements of the hypocotyl (basal) part were performed in its central part, the epicotyl part at the level of $10 \mathrm{~mm}$ above the traces of cotyledons.

To study the ultrastructure of the seed surface, the material was fixed on brass tables and sprayed with a thin layer of a mixture of platinum and gold. The ultrastruc- ture of the surface was studied using SEM JSM-6060 LA. The terminology described by W. Barthlott was used to characterize the ultrastructure of the seed coat $[11,12]$.

\section{Results of the research}

Latent period. The fruit of Uncarina roeoesliana is a dithecal flattened capsule, slightly elongated in the 
lower part, which opens at the seam, which is located in its central part. A characteristic part of the box are numerous outgrowths with hooks, which is characteristic of all members of the genus. When ripe, the fruits change colour from bright green to light brown. When the fruit falls off, a small crack first appears between the two nests, which eventually expands, but the seeds are firmly held in the fruit. Under artificial conditions, it is necessary to carefully remove the seeds from the fruit. At artificial pollination we found in fruits from 15 to 18 seeds.

Seeds form is ovoid to broadly triangular, elliptical in cross section. The wing covers the seed around the perimeter, wider in the extended part of the seed, size $7.5 \pm 0.2 \mathrm{~mm}$ long and $5.2 \pm 0.1 \mathrm{~mm}$ in the widest part. The colour of the seeds is brown, often with a grey tinge and red spots (Fig. 2, 4).

The hilum is triangular, or teardrop-shaped, without a roller, small, basal in position. Raphe is distinct, extending from the micropylar to the chalazal part of the seed. The micropylar end is slightly pointed, the micropyle stands out with a lighter colour.

The cuticle is grooved, the furrows are long, do not overlap. Cells tests are polygonal, their boundaries are clear. The periclinal walls of the seed coat cells are convex, often forming papilla, their sculpture is grooved. Anticlinal cell walls are not always thickened, straight. The relief of the seeds is reticulate. On the dorsal side of the dough seeds form folds (Fig. 3). The ventral side is smoother and has folds closer to the micropilar part of the seed (Fig. 4).
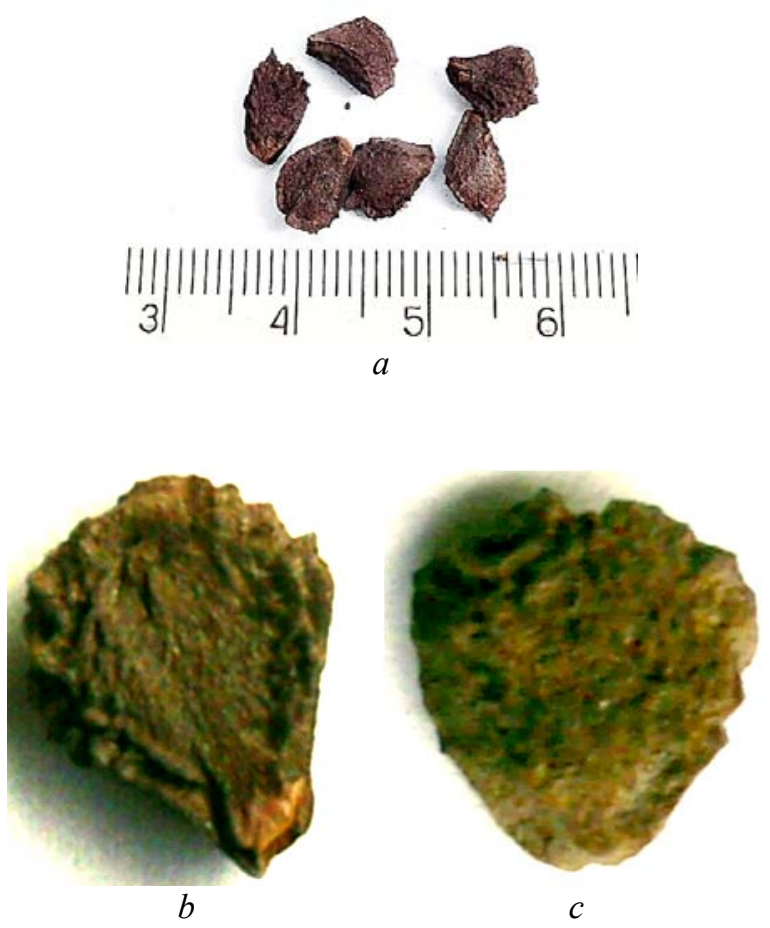

Fig. 2. Latent period: $a$ - the appearance of the seed; $b-$ ventral side of the seed $(\times 10)$; $c-$ the dorsal side $(\times 10)$
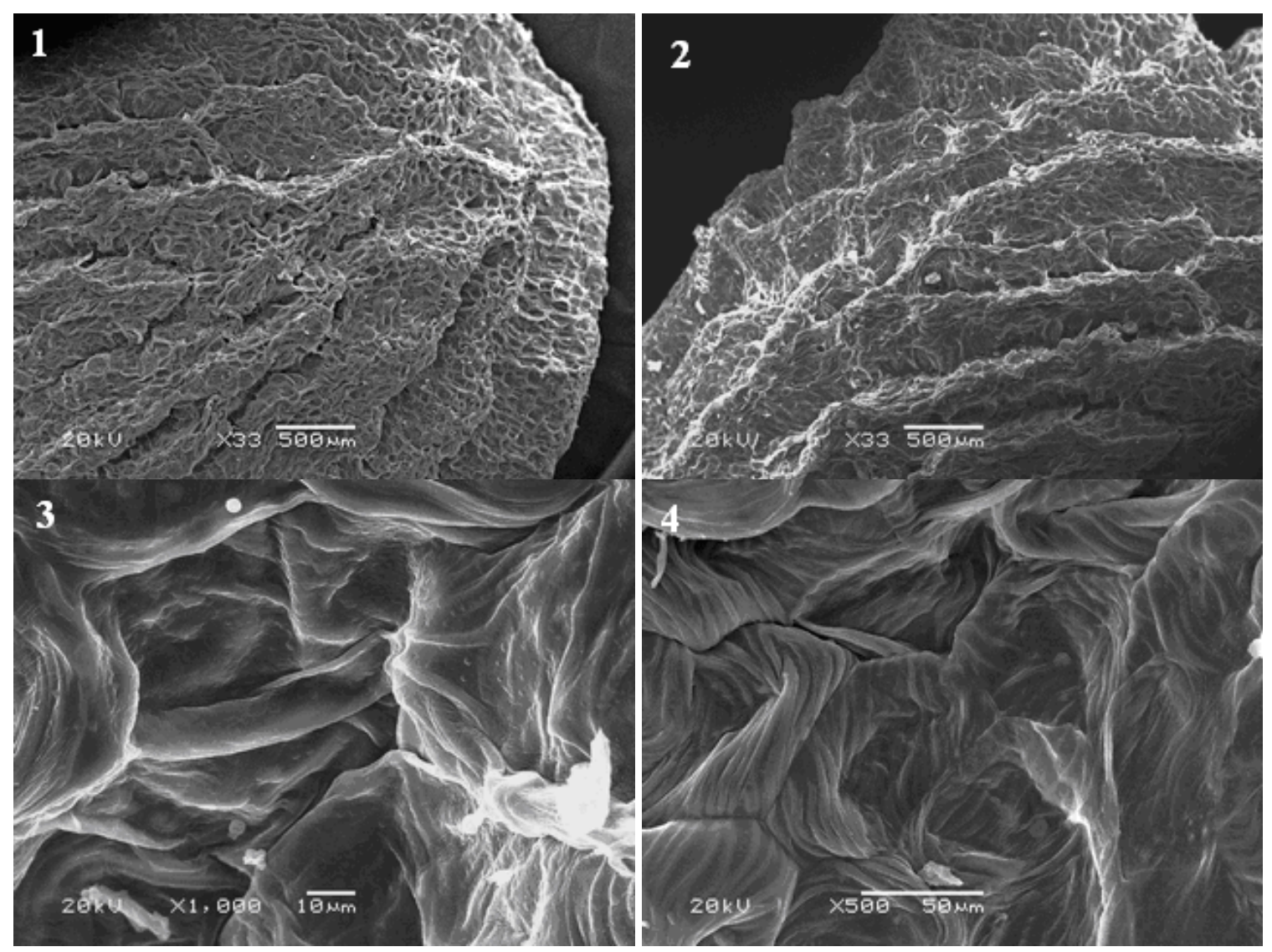

Fig. 3. Latent period. Ultrastructure of the dorsal side of Uncarina roeosliana seeds under a scanning electron microscope (SEM) 

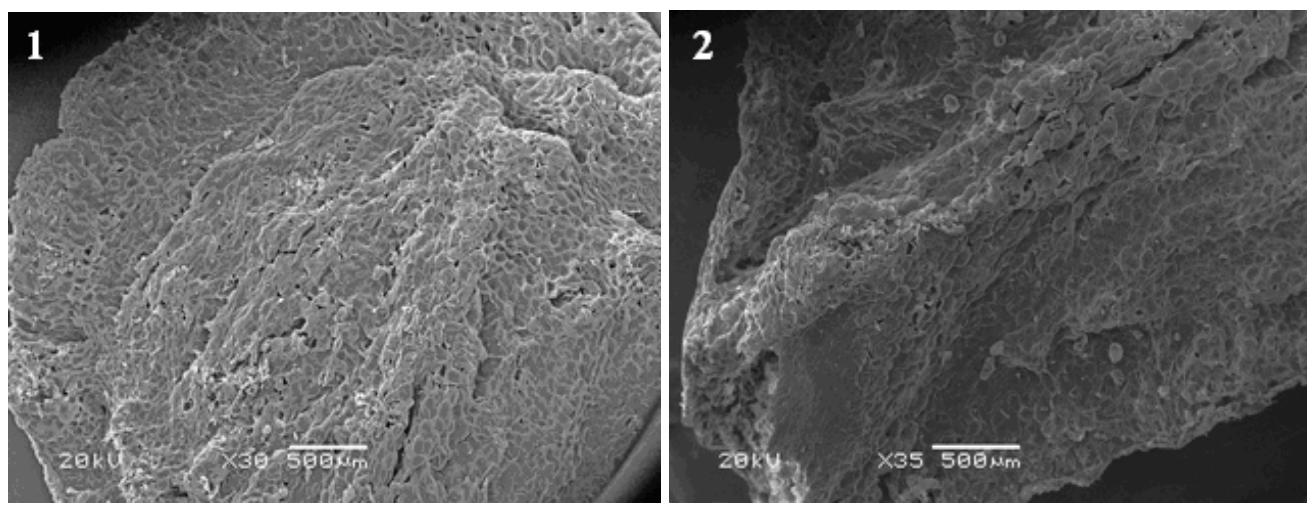

$a$

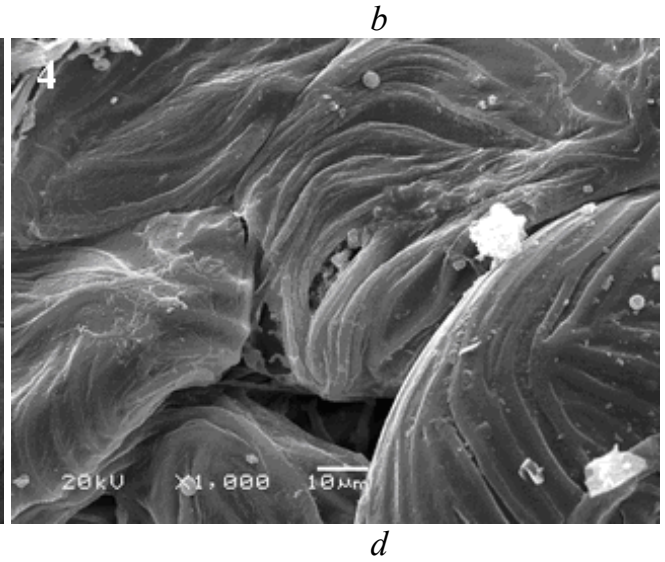

Fig. 4. Latent period. Ultrastructure of the ventral side of the seed Uncarina roesliana under a scanning electron microscope (SEM: $a, c$ - the upper part of the seed; $b, d$ - the micropillary part of the seed)

The germ is large with well-developed almost spherical cotyledons and a small hypocotyl and embryonic root. Cotyledons with pronounced veining (Fig. 5, a). Endosperm and embryo are rich in lipids (Fig. 5, $b$ ).

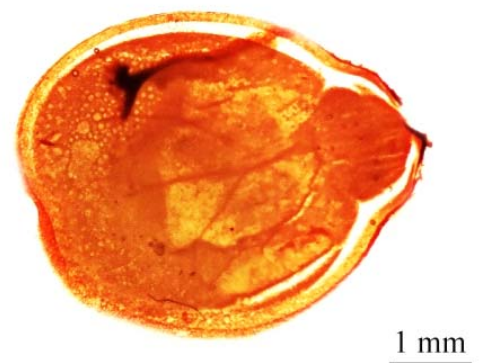

$a$

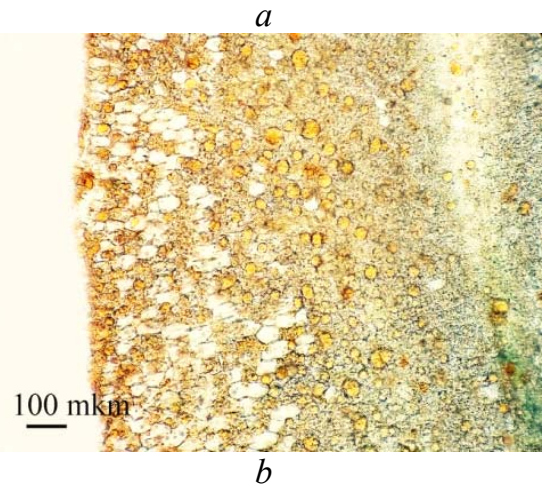

Fig. 5. Latent period: $a$ - the appearance of the germ (magnification); $b$ - endosperm with lipid inclusions
Pregenerative period. Seedling. Germination is above ground. The main root appears first, followed by the hypocotyl and cotyledons. It should be noted that in the early stages of germination (as soon as the primary root began to grow), the hypocotyl has a thickening, which disappears with further growth of the seedling and begins to reappear in the seedling 4-5 weeks after germination (Fig. 6, $a$ ). The cotyledons of the green seedling consist of a petiole $10 \mathrm{~mm}$ long and an almost rounded lamina $22 \pm 3.2 \mathrm{~mm}$ long and $20 \pm 4.2 \mathrm{~mm}$ wide. The hypocotyl and cotyledons are covered with trichomes. When germinating seeds in the laboratory on the hypocotyl can be seen trichomes at the initial stage of germination (Fig. $6, b)$. The first pair of leaves appears 10-13 days after germination, the height of the seedling is $20-25 \mathrm{~mm}$ (Fig. 7, a).

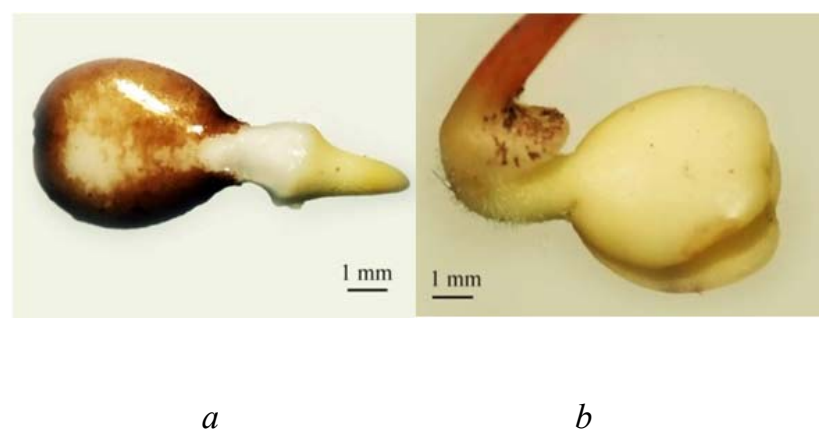

Fig. 6. The first stages of germination, the beginning of seedling development: $a$ - hypocotyl thickening; $b$ - trichomes on the hypocotyl 
Pregenerative period. Juvenile stage. Over the next 5 months, the plants form a leaf series of 5-6 pairs of leaves (Fig. 7, $a, b$ ).

Heterophylly is observed: the shape of the leaves varies from round to broadly ovate, and the sizes from $36.1 \pm 6.3 \mathrm{~mm}$ long and $27.3 \pm 5.7 \mathrm{~mm}$ wide to $100.8 \pm$ $\pm 7.2 \mathrm{~mm}$ and $116.5 \pm 12.6 \mathrm{~mm}$, respectively, the length of the petiole varies from 30 to $100 \mathrm{~mm}$. At 8-9 weeks, the plants lose their cotyledons. During the juvenile period, plants grow 5-6 pairs of leaves, two or three of which are lost by plants at the end of this period. The leaves, cotyledons and epicotyl part of the stem are densely covered with trichomes.

At the age of 4-5 weeks, the plants begin to increase the size of the hypocotyl (basal) part of the stem. Its diameter varies from $6.1 \pm 0.5 \mathrm{~mm}$ to $21 \pm 0.2 \mathrm{~mm}$ at the end of the juvenile stage, while the diameter of the epicotyl part of the stem varies from $4.0 \pm 0.2$ to $10.2 \pm \pm 0.1 \mathrm{~mm}$. Thus, if the diameter of the hypocotyl part increases 3.5 times during the juvenile stage, the epicotyl part above the traces of the cotyledons only 2.5 times (Fig. 8).

The diameter of the main root also begins to increase in plants at the age of 4 weeks. It can be formed both singly and divided into two (3) equal in size roots. Their diameter in the upper part corresponds to the diameter of the hypocotyl part of the stem.

Pregenerative period. Virginial stage in Uncarina roeoesliana begins at the age of 23-24 weeks. At the same time the leaves acquire the sizes and forms characteristic of adult plants. Plants form a rosette of two pairs of leaves, losing 3 previous pairs of leaves. The height of the stem reaches $160-190 \mathrm{~mm}$. The basal part of the stem reaches $24-26 \mathrm{~mm}$ in diameter, the root system consists of 1-2 (rarely 3 ) storage, vertical radish roots, $70-80 \mathrm{~mm}$ long, the diameter of which in the middle part is wider than the hypocotyl (basal) part of stem (Fig. 8 c). As our previous observations have shown, plants enter the generative period at the age of three to four years. In general, at the virginal stage of development, the active growth of plants decreases height, and the expansion of the hypocotyl part of the stem continues.
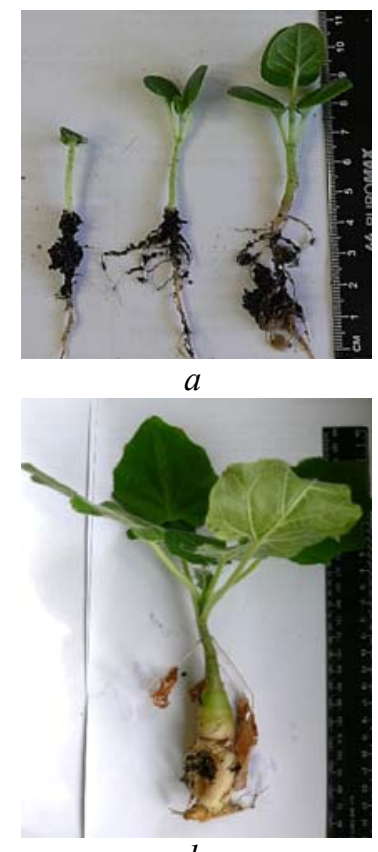

b

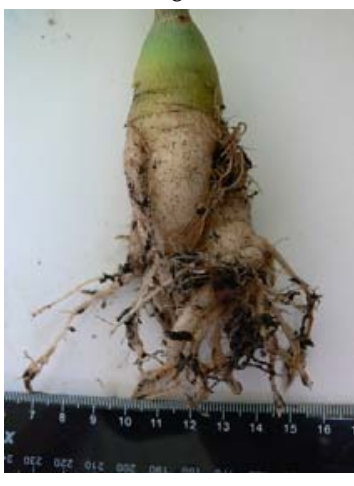

Fig. 7. Appearance of plants Uncarina roeoesliana in the early stages of development. $a$-seedling and the beginning of the juvenile stage; $b$ - completion of the juvenile stage (dead cotyledons), the formation of an expanded basal part of the stem and the first two pairs of leaves; $c$ - the volume of the root system at the virginal stage of development

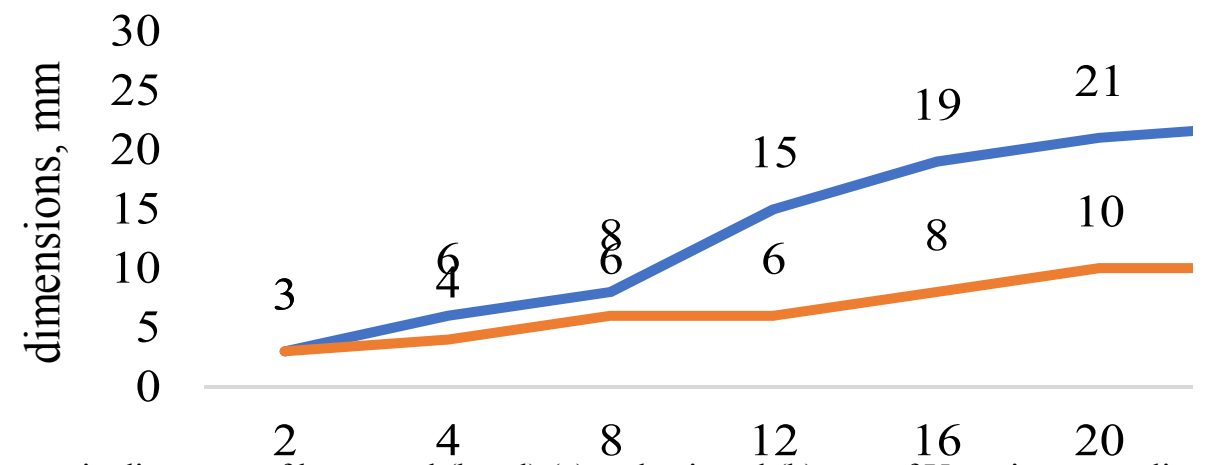

Fig. 8. Increase in diameters of hypocotyl (basal) (a) and epicotyl (b) part of Uncarina roeoesliana stem

\section{Discussion of the results}

The flora of Madagascar includes more than 10,000 species of plants. Among them are many endemic species, genera and families. According to some data, the number of such plant species reaches $85 \%$. However, all researchers, without exception, note that the flora of the 
island is catastrophically rapidly losing entire plant communities and an increasing number of endemic species is becoming highly rare [13-15]. This is especially true of many species of orchid and succulent families [16].

Investigating the features of freshly harvested seeds, we noted that only by soaking in water you can get a relatively fast germination within 10-18 days. If the seeds are sown dry, the seedlings appear singly, for 5-6 months or more. It can be assumed that the seed coat has a sufficient number of inhibitors that allow for a long time to maintain the viability of the seeds. Representatives of the family Cactaceae from the genera Opuntia and Tephrocactus have a similar feature, but the dormancy of their seeds is not so deep. In addition to moisture, high temperatures of $+30-35^{\circ} \mathrm{C}$ motivate them to germinate. [17].

The study of seed morphology under SEM showed that the surface of the seeds and the wing is quite loose and outwardly resemble a "collar structure", which probably allows the accumulation of significant moisture in the seed coat and thus reduce the concentration of inhibitors and promote lipid breakdown, which are storage substances, to the formation of more available for seed germination substances. The conclusions regarding lipids should be revised taking into account the literature data on the germination of oilseeds. The maximum activity of enzymes that break down lipids (including lipoxygenase) is manifested at seed moisture of at least $14-15 \%$ and a temperature of $50^{\circ} \mathrm{C}[18]$.

It should be noted that the amount of lipids in the seeds of the most famous member of this family Sesamum indicum L. is also quite high, up to 50-60\% [3]. All these features of seed germination are consistent with the ecological conditions in the natural habitats of the genus Uncarina: high temperatures, low rainfall and a significant drought. Probably plants of this species are macrobiotics, i.e. can retain seed germination long enough.

It should be noted that Uncarina roeoesliana belong to the caudex-like succulents and, as well as Adenium obesum (Forssk.) Roem. and Schult. (Apocynaceae) have an enlarged basal part of the stem, formed from the hypocotyl of the seedling, and a rod succulent root, the diameter of which in the early stages of development is almost the same as the diameter of the basal part of the stem $[19,20]$. But, unlike Adenium obesum, the leaves of this plant have no xeromorphic features and wither when there is a lack of moisture in the soil and high temperatures in the environment. That is, despite the thickened basal part of the stem and roots, plants of this species are prone to leaf loss with insufficient moisture in the soil. In this case, after the loss of leaves, the plants experience a dry period without damage, which can last up to 7 months in a row.

Study limitations. The presented results are an integral part of the cycle of morphological studies Uncarina roeoesliana. Thus, at the first stage of research of the endemic plant of Madagascar Uncarina roeoesliana we described the morphology of the flower, studied the features of pollination and developed a method of obtaining seeds under the conditions of introduction. At the second stage (this article) we studied the morphology of seeds, plant development at the pregenerative stage of development and developed a method of germination of seeds obtained under conditions of cultivation in protected soil.

Prospects for further research. In the future it is necessary to find out in more detail the structure of the seed coat of Uncarina roeoesliana, the shelf life of seed germination under different storage conditions, as well as to identify substances that inhibit the germination of seeds of this species.

\section{Conclusions}

1. Comparing Uncarina roeoesliana with other caudex-like plants, it can be stated that this plant has a high potential for survival in arid conditions due to the plant's ability to accumulate moisture in the basal part of the stem and fleshy root. In this case, the plant is adapted to exist both in dormancy (losing leaves and using moist roots) and in the mode of active growth, but in the presence of sufficient moisture in the soil. These features distinguish it from other caudex-like plants.

2. Examination of the morphology of Uncarina roeoesliana seeds revealed an inconspicuous wing and convex cell walls of the seed coat, which are likely to be able to accumulate a significant amount of moisture to activate the germination process.

3. A method of seed germination of Uncarina roeoesliana has been developed.

\section{Conflict of interests}

The authors declare that they have no conflicts of interest.

\section{References}

1. Eggli, U., Albers, F.; Eggli, U. (Ed.) (2002). Illustrated Handbook of succulent plants. Dicotyledones. New York, Berlin, Heidelberg: Springler-Verlag, 547.

2. Jacobsen, H. (1970). Das sukkulentenlexicon. Jena: VEB Gustav Fischer Verlag, 642

3. Mirey, S., Kiani, S. (2016). Bioactivity of Sesamum indicum: a review study. Der Pharmacia Lettre, 8 (6), 328-334.

4. Maksymov, Y. M. (Ed.) (1990). Madahaskar. Moscow: Prohress, 280.

5. Gaidarzhi, M., Nuzhina, N. (2019). Morphology, phenology and fruiting of Uncarina roeoesliana Rauh in culture. Visnyk of Lviv University. Biological Series, 80, 59-66. doi: http://doi.org/10.30970/vlubs.2019.80.07

6. Danilova, M. F. (1996). Semeistvo Crassulaceae 11. Sravnitelnaia anatomiia semian. Vol. 5. Dvudolnye. Rosidae. Saint Petersburg: Mir i semia, 25-34.

7. Takhtadzhian, A. L. (1987). Sistema magnoliofitov. Leningrad: Nauka, 438.

8. Corner, E. J. H. (1976). The seeds of dicotyledons. Vol. 1. Cambridge: Cambridge University Press, 311.

9. Zhmylev, P. Iu., Alekseev, Iu. E., Karpukhina, E. A., Balandin S. A. (2005). Biomorfologiia rastenii: illiustrirovannii slovar. Moscow: Grif, 256.

10. Shyrobokova, D. N., Nikitina, V. V., Haidarzhy, M. M., Bahlai, K. M. (2003). Kaktusy ta inshi sukulentni roslyny. Kyiv: Ukrainski propilei, 108. 
11. Barthlott, W. (1981). Epidermal and seed surface characters of plants: systematic applicability and some evolutionary aspects. Nordic Journal of Botany, 1 (3), 345-355. doi: http://doi.org/10.1111/j.1756-1051.1981.tb00704.x

12. Barthlott, W. (1984). Microstructural features of seed surfaces. Syst. Assoc. Spec, 25, 95-105.

13. Brown, K. A., Parks, K. E., Bethell, C. A., Johnson, S. E., Mulligan, M. (2015). Predicting Plant Diversity Patterns in Madagascar: Understanding the Effects of Climate and Land Cover Change in a Biodiversity Hotspot. PLOS ONE, 10 (4), e0122721. doi: http://doi.org/10.1371/journal.pone.0122721

14. Callmander, M. W., Phillipson, P. B., Schatz, G. E., Andriambololonera, S., Rabarimanarivo, M., Rakotonirina, N. et. al. (2011). The endemic and non-endemic vascular flora of Madagascar updated. Plant Ecology and Evolution, 144 (2), 121-125. doi: http://doi.org/10.5091/plecevo.2011.513

15. Morat, P., Lowry, P. P. (1977). Floristic richness in the Africa-Madagascar region: a brief history and properties. Adansonia, 19 (1), 101-115.

16. Gaidarzhi, M. N. (2014). Botanicheskaia ekskursiia na ostrov Madagaskar. Sokhranenie bioraznoobraziia i introdukciia rastenii. Kharkiv, 19-24.

17. Haidarzhy, M. M., Nikitina, V. V., Bahlai, K. M., Kalashnyk, S. O. (2011). Adaptatsiini stratehii sukulentnykh roslyn u preheneratyvnyi period. Vidnovlennia porushenykh pryrodnykh ekosystem. Donetsk, 90-92.

18. Scherbakov, V. G., Lobanov, V. G. (2003). Biokhimiia i tovarovedenie maslichnogo syria. Moscow: Kolos, 360.

19. Avekin, Ya., Haidarzhy, M. (2017). Adenium obesum (Forssk.) Roem. \& Schult. (Apocynaceae): development of vegetative organs in the early stages of ontogenesis. Ukrainian Journal of Ecology, 7 (2), 173-183. doi: http://doi.org/10.15421/2017_34

20. Haidarzhy, M., Nikitina, V., Bahlai, K., Kalashnyk, S. (2015). Kaudeksni sukulentni roslyny v kolektsii Botanichnoho sadu. Visnyk Kyivskoho Natsionalnoho Universytetu imeni Tarasa Shevchenka. Introduktsiia ta zberezhennia roslynnoho riznomanittia, 33, 11-14.

Received date 14.02.2020

Accepted date 04.03.2020

Published date 30.04.2020

Maryna Gaidarzhy, Doctor of Biological Sciences, Leading Researcher, Educational and Research Center "Institute of Biology and Medicine" Taras Shevchenko National University of Kyiv, Volodymyrska str., 64/13, Kyiv, Ukraine, 01601

E-mail: gaidarzhy@ukr.net

Oksana Futorna, PhD, Educational and Research Center "Institute of Biology and Medicine" Taras Shevchenko National University of Kyiv, Volodymyrska str., 64/13, Kyiv, Ukraine, 01601

E-mail: oksana_drofa@yahoo.com

Nataliia Nuzhyna, PhD, Educational and Research Center "Institute of Biology and Medicine" Taras Shevchenko National University of Kyiv, Volodymyrska str., 64/13, Kyiv, Ukraine, 01601

E-mail: nuzhynan@gmail.com 